\title{
Effect of Different Sowing Dates on Growth and Yield of Kharif Sorghum Hybrids
}

\author{
${ }^{1}$ M. B. Karhale, ${ }^{2}$ Jaybhaye P. R, ${ }^{3}$ Asewar B.V, ${ }^{4}$ Shinde P.B \\ Department of Agricultural Meteorology, \\ Vasantrao Naik Vasantrao Naik Marathwada Krishi Vidyapeeth, Parbhani-431 402 (MS), India
}

\begin{abstract}
The experiment was conducted on experimental farm of Department of Agricultural Meteorology, College of Agriculture, Vasantrao Naik Marathwada Krishi Vidyapeeth, Parbhani, during kharif season 2012-13 entitled as "Yield Forecasting of Sorghum by using Statistical Model" to find out most optimum meteorological week for sowing sorghum in kharif season, to study the relationship between meteorological parameters and yield and to develop statistical model for yield forecasting. The results were obtained from the experiment it was found that all the biometric observations (plant height, number of leaves, leaf area, LAI and dry matter) in kharif sorghum were significantly highest in treatment of sowing in 24 MW (11 to 17 June) followed by second sowing date 25 MW (18 to 24 June). Amongst the varieties all the biometric observations were recorded significantly highest in $V_{l}(P S H-71)$. Sowing in $24 M W$ significantly superior over the rest of treatments with production of highest grain yield $1482.10 \mathrm{~kg} \mathrm{ha}^{-1}$ followed by sowing in second sowing date $25 \mathrm{MW} 1444.2 \mathrm{~kg} \mathrm{ha}^{-1}$ which was at par with sowing in $24 \mathrm{MW}$ in respect to all yield attributing characters and lowest grain yield was observed in fourth sowing i.e $27 \mathrm{MW} 1119.31 \mathrm{~kg} \mathrm{ha}^{-1}$. Hence, sowing of kharif sorghum should be completed on $24 \mathrm{MW}$ or before $25 \mathrm{MW}$; otherwise there is chance of reduction of grain yield with delayed sowing.
\end{abstract}

Key words: Kharif sorghum, sowing dates, yield attributes.

\section{Introduction}

Sorghum (Sorghum bicolor (L.) Moench) is an important food crop in India and it is cultivated in tropical and subtropical climates, especially in the semi-arid tropics. It is the fifth most important cereal crop followed by rice, wheat, maize and barley in the world. In India, sorghum is extensively produced and both hybrid and improved varieties of sorghum are taken on large scale. In Maharashtra state, during kharif season jowar is cultivated on 8.82 Mha with production $1.342 \mathrm{Mt}$ and productivity of $1498 \mathrm{~kg} / \mathrm{hectare}$. Rabi Sorghum plays an important role in dry land economy In Maharashtra. The area under rabi sorghum during 2011-12 was 2.38 lakhs hectare with production $1.35 \mathrm{Mt}$ and productivity $567 \mathrm{~kg} /$ hectare (Anonymous 2012). Dryland farming is the backbone of Indian agriculture, as large areas of cultivated land are rainfed. The success or failure of dryland rainfed crops depends mostly on the pattern of monsoon rains. The distribution of rainfall in monsoon decides the yield of rainfed crops. To mitigate these losses of kharif sorghum, a field experiment was conducted to find out the suitable sowing date for sustainable yield of rainfed kharif sorghum under erratic behavior of monsoon.

\section{Material And Methods}

The experiment was conducted on experimental farm of Department of Agricultural Meteorology, College of Agriculture, Vasantrao Naik Marathwada Krishi Vidyapeeth, Parbhani, during kharif season 2012-13. The experiment was conducted in split plot design with three replications. Treatment under study were four sowing dates as main treatment in kharif season i.e. $24^{\text {th }} \mathrm{MW}, 25^{\text {th }} \mathrm{MW}, 26^{\text {th }} \mathrm{MW}$ and $27^{\text {th }} \mathrm{MW}$, and four different varieties as sub treatment i.e. PSH-71, MSH-51, BGL-296 and PVK-801 were sown with spacing $45 \times 15 \mathrm{~cm}$. The gross plot size was $3.60 \times 2.25 \mathrm{~m}^{2}$ and net plot size was $2.25 \times 1.8 \mathrm{~m}^{2}$. The sowing of seed was done by dibbling method on respective date of sowing. Recommended packages of practices like thinning, weeding, application of recommended dose of fertilizer and pesticide were uniformly followed for each experiment. Observations were recorded on five plants randomly selected per treatment.

\section{Results And Discussion}

\section{Weather condition during crop growth}

Total rainfall during crop growth period (24 MW to $45 \mathrm{MW}$ ) received was $673.9 \mathrm{~mm}$ in 41 rainy days. The maximum and minimum temperature during crop growing period was ranged in between 30.0 to $38.4{ }^{\circ} \mathrm{C}$ and 15.6 to $26.3{ }^{\circ} \mathrm{C}$ respectively. The morning relative humidity (RH-I) ranged from 61.0 to 95.0 percent during crop growing season and RH-II ranged in between 26.0 to 72.0 percent during crop growing season. 
It is observed that lowest and highest EVP $2.8 \mathrm{~mm}$ in $36^{\text {th }} \mathrm{MW}$ and $11.2 \mathrm{~mm}$ in $24^{\text {th }} \mathrm{MW}$ respectively. The mean BSS during crop growing period (from $24^{\text {th }}$ to $45^{\text {th }} \mathrm{MW}$ ) were 6.39 hrs per day. It was observed that the highest value of bright sunshine hours $10.1 \mathrm{hrs} \mathrm{day}^{-1}$ were recorded in $42 \mathrm{MW}$ while, lowest BSS $2.7 \mathrm{hrs}$ per day in $25 \mathrm{MW}$. Highest wind velocity $7.9 \mathrm{kmhr}^{-1}$ was recorded in $24^{\text {th }} \mathrm{MW}$, while lowest wind velocity 2.0 $\mathrm{kmhr}^{-1}$ was recorded in $41 \mathrm{MW}$.

\section{Growth components}

a) Plant height: - The plant height was observed significantly highest in first date of sowing i.e. $24 \mathrm{MW} 157.0$ $\mathrm{cm}$ at harvest than other date of sowing at all stages of crop growth. Lowest plant height was recorded in 27MW during all growth stages of crop. However, in $25 \mathrm{MW}$ and $26 \mathrm{MW}$ sowing plant height was observed at par with $24 \mathrm{MW}$ at all the growth stages of crop. Among varieties variety $\mathrm{V}_{1}$ (PSH-71) recorded significantly highest plat height than other varieties in all growing stages. The interaction effect between date of sowing and varieties was found non significant at all stages. Similar results for date of sowing for plant height were given by Iyanar et al. (2001), Shivadhara et al. (2005), Sonwar et al. (2008)

b) Number of functional leaves: - The mean number of leaves per plant was observed significantly highest in first date of sowing i.e. $24 \mathrm{MW}$ (24 MW). Among varieties numbers of functional leaves were recorded significantly highest in $\mathrm{V}_{1}$ (PSH-71) i.e. 9.76 per plant. The interaction effect between date of sowing and varieties was found non significant at all stages. Similar results for sowing dates and varieties in number of leaves in sorghum were given by Shivadhar et al. (2005) and Sonwar et al. (2008).

c) Leaf area plant ${ }^{-1}$ :- Leaf area were observed significantly highest in first sowing $24 \mathrm{MW} 4144.3 \mathrm{~cm}^{2}$ over all sowing dates. While, it was at par with second date of sowing $(25 \mathrm{MW})$ at all the stages of crop growth. However, lowest leaf area was recorded in 27MW during all growth stages. Significantly highest leaf area was observed in $\mathrm{V}_{1}$ i.e. (PSH-71) during all growing stages, expect in $\mathrm{V}_{2}$ leaf area observed significantly highest at 60 DAS. While, the lowest leaf area was observed in $\mathrm{V}_{4}$ (PVK-801) consistently up to harvest.

d) Dry matter production:- Significantly superior and highest dry matter was observed in sowing 24 MW (24 MW) at all growth stages than other date of sowing dates and it was at par with second sowing (25 MW) at 60 DAS. Among varieties significantly highest dry matter was observed in $\mathrm{V}_{1}$ (PSH-71) at all the growth stages than other three varieties $\left(\mathrm{V}_{2}, \mathrm{~V}_{3}\right.$ and $\left.\mathrm{V}_{4}\right)$.

\section{Phenological parameters}

a) Number of days required for $\mathbf{5 0}$ percent flowering:- The mean number of days required to 50 percent flowering was observed that $24 \mathrm{MW}$ require significantly highest days to flowering (75.91 days) while, 27MW flowered significantly earlier (68.58 days) than other date of sowing. Similar results were reported by Baig and Shankiti (1994) for different date of sowing affects on $50 \%$ flowering. Among varieties $\mathrm{V}_{2}$ flowered significantly earlier (71.66 days) and highest days require to $V_{1}$ ( 72.50 days) and it was at par with all varieties.

b) Number of days required for physiological maturity:- Among the treatments of sowing in $24^{\text {th }} \mathrm{MW}$ matured significantly late (114.50 days) while $27 \mathrm{MW}$ matured significantly earlier (105.5 days) than other date of sowing. It means that temperature gradient, low soil moisture and less quantum of rainfall early maturity was forced 27MW sowing naturally. It mature 10 days earlier than sowing.

\section{Yield attributes}

a)Test weight (gm) :- It was observed from data, that the mean test weight of kharif sorghum varieties was $30.43 \mathrm{gm}$ per 1000 seeds. The effect of different date of sowing on thousand seed weight (gm) was found to be significant. The second sowing $25 \mathrm{MW}$ ( $25 \mathrm{MW}$ ) showed significantly highest mean thousand seed weight over other date of sowing and it was at par with $24 \mathrm{MW}$ and 26MW sowing date.

Sonwar et al. (2008) reported that the early sowing of kharif sweet sorghum gives highest test weight.

The effect of all four varieties on thousand seed weight was found significant. The variety $\mathrm{V}_{1}$ (PSH-71) found to be significantly superior $(31.83 \mathrm{gm})$ in mean thousand seed weight than other varieties. While, it was at par with $\mathrm{V}_{3}$ (BGL-296). It because of varietal characters i.e. yield response to weather parameters. The interaction effect between date of sowing and different cultivars was found to be non significant.

b) Grain yield $\left(\mathrm{kg} \mathrm{ha}^{-1}\right)$ :-The data indicated that mean grain yield per hectare of kharif sorghum was $1335.9 \mathrm{~kg}$ $\mathrm{ha}^{-1}$. The data on mean seed yield indicated that among the sowing dates the crop sown in first sowing date 24 MW $\left(24^{\text {th }} \mathrm{MW}\right)$ recorded significantly highest grain yield $\left(1482.10 \mathrm{~kg} \mathrm{ha}^{-1}\right)$ and lowest grain yield was observed in fourth sowing $27 \mathrm{MW}\left(27^{\text {th }} \mathrm{MW}\right) .24 \mathrm{MW}$ was significantly superior over $26 \mathrm{MW}$ and $27 \mathrm{MW}$ while, it was at par with second sowing date $25 \mathrm{MW}\left(25^{\text {th }} \mathrm{MW}\right)$ and recorded seed yield $1444.2 \mathrm{~kg} \mathrm{ha}^{-1}$.

Similar results were reported by Firke and Kadam (1979), Umrani et al. (1988), Baig and Shankiti (1994), Bhoite and Nimbalkar (1997), Sunil Kausik et al. (2007), Jadhav et al. (2010). Also the results are conformity with Mishra et al. (2011). 
Among the four varieties highest grain yield per ha ${ }^{-1}$ was observed in variety $\mathrm{V}_{1}$ (PSH-71) $1451.31 \mathrm{~kg}$ $\mathrm{ha}^{-1}$ and lowest in $\mathrm{V}_{4}\left(1230.2 \mathrm{~kg} \mathrm{ha}^{-1}\right)$. The variety $\mathrm{V}_{1}$ was recorded significantly superior yield over all the other varieties. The interaction effect between date of sowing and different varieties was found to be non significant for grain yield.

c) Fodder yield :- Data revealed that mean fodder yield of kharif sorghum influenced by different treatments and over all mean was recorded $6908.9 \mathrm{~kg} \mathrm{ha}^{-1}$. Among the sowing dates second sowing date $25 \mathrm{MW}\left(25^{\text {th }} \mathrm{MW}\right)$ significantly highest fodder yield $\left(7310 \mathrm{~kg} \mathrm{ha}^{-1}\right)$ was recorded and lowest in $27 \mathrm{MW}\left(6541.1 \mathrm{~kg} \mathrm{ha}^{-1}\right)$. While, it was at par with first date of sowing $24 \mathrm{MW}\left(7261.3 \mathrm{~kg} \mathrm{ha}^{-1}\right)$.Similar results were reported by Alma et al. (1995). The data on fodder yield indicated that significant difference amongst the varieties and it was observed that fodder yield highest and lowest recorded in $V_{1}\left(7228.2 \mathrm{~kg} \mathrm{ha}^{-1}\right)$ and $\mathrm{V}_{2}\left(6484.7 \mathrm{~kg} \mathrm{ha}^{-1}\right)$ respectively. While, it was at par with $\mathrm{V}_{2}\left(7069.9 \mathrm{~kg} \mathrm{ha}^{-1}\right)$.

d) Biological yield :- Among the sowing dates second sowing date $24 \mathrm{MW}\left(24^{\text {th }} \mathrm{MW}\right)$ significantly highest biological yield was recorded $\left(8743.4 \mathrm{~kg} \mathrm{ha}^{-1}\right)$ and lowest in 27MW $\left(7660.41 \mathrm{~kg} \mathrm{ha}^{-1}\right)$. While, it was at par with second date of sowing 25MW (8741.8 $\left.\mathrm{kg} \mathrm{ha}^{-1}\right)$.Similar results are reported by Suchit K Rai et al. (2006). Among the four varieties highest biological yield was observed in variety $\mathrm{V}_{1}(\mathrm{PSH}-71) 8679.51 \mathrm{~kg} \mathrm{ha}^{-1}$ and lowest in $\mathrm{V}_{2}$ $\left(7794.2 \mathrm{~kg} \mathrm{ha}^{-1}\right)$. While, it was at par with $\mathrm{V}_{3}\left(8422.6 \mathrm{~kg} \mathrm{ha}^{-1}\right)$.

\section{Conclusion}

On the basis of observations tabulation and analysis of data i.e. biometric and yield contributing character it was observed 24 MW sowing i.e. 24 MW (11 to 17 June) was showed significantly superior over rest of treatments with production of highest grain yield $\left(1482.10 \mathrm{~kg} \mathrm{ha}^{-1}\right)$ and total biological yield $(8743.4 \mathrm{~kg}$ $\mathrm{ha}^{-1}$ ), followed by in second sowing date $25 \mathrm{MW}$ in $25 \mathrm{MW}$ (18 to 24 June) which is at par with $24 \mathrm{MW}$. It is therefore, recommended that sowing may be done in $24 \mathrm{MW}(24 \mathrm{MW})$ (11 to 17 June) for highest grain yield, followed by $25 \mathrm{MW}$ (25 MW) (18 to 24 June) and variety $\mathrm{V}_{1}$ (PSH-71) recommended for sowing in kharif season on the basis highest grain yield as well as fodder yield at Parbhani location.

[1]. Anonymous. 2012. Error! Hyperlink reference not valid.

[2]. Alma D. Baez-Gomzaler and J. G. W. Jones. 1995. Models of sorghum and perlmillet to predict the forage dry matter production in semi aerid mexico. 2 Regression models. Agricultural system 47: 147-159

[3]. Baig, M. S., A. AL-Shankiti. 1994. Effect of sowing dates on different parental lines of sorghum hybrids PKV Res. J. Vol. 18(2): 206-208.

[4]. Bhoite S. V. and Nimbalkar. 1997. Performance of kharif crops under different planting time J. of Maharashtra Agric. University. 22(1): 345-346.

[5]. Firke P. V. and M. V. Kadam. 1979. Effect of sowing dates and seed rates on the incidence of Atherigona soccata Rond. And grain yield of some sorghum varieties. J. Mahrashtra Agric. Univ., 4(1): 69-74.

[6]. Iyanark, K., A. Gopalan and P. Ramasamy. 2001. Correlation and path analysis is sorghum. Ann. Agric. Res. 22(4): $495-497$.

[7]. Jadhav, M. G., V. G. Maniyar and G. R. More. 2010. Influence of changes in weather on phenology and grain yield of kharif sorghum at parbhani in Maharashtra. ISPRS Archives xxxVIII-8w3 workshop proceeding. Impact of climate change on Agriculture 401

[8]. Mishra, J. S., M. S. Raut, Pushpendra Singh, R. Kalpana, V. S. Khubsed, O. G. Lokhande, Z. N. Patel, N. S. Thakur, S. M. Nema de, Sampadana Bhat, Pramod Kumar, Kewalanand. 2011. Agronomy Kharif Report. pp

[9]. Shivadhar, S. D. Gupta, S. N Tripathi and Suchit K Rai. 2005. Production potential of fodder sorghum varieties under different nitrogen levels and sowing dates. Indian J. of Agricultural Sciences., 75(3): 572-575.

[10]. Sonwar, S. N., A. G. Wani, D. P. Dacharne, H. M. Patil. 2008. Effect of seeding dates and planting layouts on growth, Juice quality and grain yield of sweet sorghum. J. Maharashtra agric. Univ., 33(1): 108-110.

[11]. Sunil Kausik, K. K. Singh, D. J. Jiotode and A. K. Baxla. 2007. Exploring application of seasonal climate forecast using viable management option in sorghum at Akola, Maharashtra, India. Journal of Agro-meteorology., 9(1): 11-19.

[12]. Suchit K. Rai, BRD Gupta and Sunil Kumar. 2006. Simulation as tool for analyzing climatic risk to forage sorghum production in semi-arid region of India: Effect of cultivar and planting date. Indian J. of Agricultural Sciences., 76(3): 162-166.

[13]. Umrani, N. K., D. G. Ramshe, A. C. Joshi and K. V. Rao. 1988. Loss in yield of sorghum entries due to late sowing under varying NPK fertilization. J. Maharashtra agric. Univ., 13(2): 127-128.

Table 1: - Different growth attributes

\begin{tabular}{|c|c|c|c|c|c|c|c|}
\hline Treatments & $\begin{array}{l}\text { Plant height } \\
(\mathrm{cm}) \text { at } \\
\text { harvest }\end{array}$ & $\begin{array}{ll}\text { No } & \text { of } \\
\text { leaves at } & \text { at } \\
60 \text { DAS } & \end{array}$ & $\begin{array}{l}\text { Leaf area } \\
\left(\mathrm{cm}^{2}\right) \text { at } 60 \\
\text { DAS }\end{array}$ & $\begin{array}{lr}\text { Dry } & \text { matter } \\
(\mathrm{gm}) & \text { at } \\
\text { harvest } & \end{array}$ & $\begin{array}{l}\text { Days to } 50 \% \\
\text { flowering } \\
\text { (DAS) }\end{array}$ & $\begin{array}{l}\text { Days } \\
\text { Maturity } \\
\text { (DAS) }\end{array}$ & to \\
\hline \multicolumn{8}{|l|}{ Sowing Dates } \\
\hline $24 \mathrm{MW}$ & 157.00 & 9.91 & 4144.3 & 139.26 & 75.91 & 114.50 & \\
\hline $25 \mathrm{MW}$ & 156.28 & 9.05 & 3933.3 & 130.07 & 73.33 & 109.70 & \\
\hline $26 \mathrm{MW}$ & 153.84 & 8.99 & 3913.8 & 129.97 & 70.50 & 106.67 & \\
\hline $27 \mathrm{MW}$ & 136.20 & 7.76 & 3375.1 & 127.96 & 68.58 & 105.50 & \\
\hline S.E. \pm & 2.26 & 0.37 & 98.09 & 1.92 & 0.54 & 0.30 & \\
\hline $\mathrm{CD}$ at $5 \%$ & 6.59 & 1.08 & 285.88 & 5.59 & 1.62 & 0.87 & \\
\hline \multicolumn{8}{|l|}{ Varieties } \\
\hline $\mathrm{V}_{1} \quad$ PSH-71 & 157.56 & 9.76 & 3931.1 & 134.57 & 72.50 & 110.33 & \\
\hline
\end{tabular}


Effect of Different Sowing Dates on Growth and Yield of Kharif Sorghum Hybrids

$\begin{array}{lllllll}\text { V }_{2} \text { MSH-51 } & 145.01 & 8.91 & 3946.8 & 133.45 & 71.66 & 107.92 \\ \text { V }_{3} \text { BGL-296 } & 149.64 & 9.12 & 3832.5 & 129.84 & 72.00 & 109.17 \\ \text { V }_{4} \text { PVK-801 } & 151.11 & 7.91 & 3656.2 & 129.40 & 72.16 & 109.00 \\ \text { SE } \pm & 1.50 & 0.34 & 46.67 & 1.16 & 0.54 & 0.35 \\ \text { CD at 5 \% } & 4.41 & 1.00 & 136.03 & 3.39 & 1.72 & 1.04 \\ \text { D x V Interaction } & & & & & & \\ \text { S.E } \pm & 3.01 & 0.69 & 93.34 & 2.33 & 1.08 & 0.71 \\ \text { CD at 5 \% } & \text { NS } & \text { NS } & \text { NS } & \text { NS } & \text { NS } & \text { NS } \\ \text { G.M } & 150.83 & 8.93 & 3841.6 & 131.82 & 72.08 & 109.1\end{array}$

Table 2:- Mean test weight (gm), grain yield $\left(\mathrm{kg} \mathrm{ha}^{-1}\right)$, fodder yield $\left(\mathrm{kgha}^{-1}\right)$ and biological yield $\left(\mathrm{kg} \mathrm{ha}^{-1}\right)$ influenced by different treatments.

\begin{tabular}{|c|c|c|c|c|c|}
\hline Treatments & Test weight $\quad(g m)$ & $\begin{array}{l}\text { Grain yield (kg ha } \\
\left.{ }^{1}\right)\end{array}$ & $\begin{array}{l}\text { Fodder yield } \\
\text { ha' }^{-1} \text { ) }\end{array}$ & (kg & $\begin{array}{l}\text { Biological } \\
\left(\mathrm{kg} \mathrm{ha}^{-1}\right)\end{array}$ \\
\hline \multicolumn{6}{|c|}{ Date of Sowing } \\
\hline $24 \mathrm{MW}$ & 30.60 & 1482.10 & 7261.3 & & 8743.4 \\
\hline $25 \mathrm{MW}$ & 31.66 & 1431.30 & 7310.5 & & 8741.8 \\
\hline $26 \mathrm{MW}$ & 31.28 & 1311.00 & 6522.6 & & 7833.6 \\
\hline $27 \mathrm{MW}$ & 28.19 & 1119.31 & 6541.1 & & 7660.41 \\
\hline $\mathrm{SE} \pm$ & 0.76 & 26.62 & 174.46 & & 178.62 \\
\hline $\mathrm{CD}$ at $5 \%$ & 2.24 & 77.59 & 508.46 & & 520.56 \\
\hline \multicolumn{6}{|l|}{ Varieties } \\
\hline$V_{1}$ PSH-71 & 31.83 & 1451.31 & 7228.2 & & 8679.51 \\
\hline $\mathrm{V}_{2}$ MSH-51 & 29.25 & 1309.50 & 6484.7 & & 7794.2 \\
\hline$V_{3}$ BGL-296 & 31.08 & 1352.7 & 7069.9 & & 8422.6 \\
\hline $\mathrm{V}_{4}$ PVK-801 & 29.58 & 1230.2 & 6847.7 & & 8077.9 \\
\hline $\mathrm{SE} \pm$ & 0.50 & 23.23 & 179.77 & & 183.96 \\
\hline $\mathrm{CD}$ at $5 \%$ & 1.47 & 67.71 & 523.92 & & 536.13 \\
\hline \multicolumn{6}{|c|}{ D x V Interaction } \\
\hline $\mathrm{SE} \pm$ & 1.01 & 46.47 & 359.54 & & 367.91 \\
\hline $\mathrm{CD}$ at $5 \%$ & NS & NS & NS & & NS \\
\hline G.M & 30.43 & 1335.9 & 6908.9 & & 8244.21 \\
\hline
\end{tabular}

